\title{
Antimicrobial profile of Acinetobacter baumannii at a tertiary hospital in Honduras: a cross-sectional analysis
}

\author{
Julio Cesar Zuniga-Moya, ${ }^{1}$ Clerk Annette Caballero, ${ }^{1}$ Mariela Loucel-Linares, ${ }^{1}$ \\ Mayra Jazmin Benitez, ${ }^{1}$ Edoardo Zambrano-Garcia, ${ }^{1}$ Lidice Vanesa Fajardo, ${ }^{1}$ \\ Julissa Stephanie Paz, ${ }^{1}$ Suyapa A. Bejarano, ${ }^{1}$ Emilio Barrueto Saavedra, ${ }^{2}$ and Luis Enrique Romero ${ }^{2}$
}

\begin{abstract}
Suggested citation Zuniga-Moya JC, Caballero CA, Loucel-Linares M, Benitez MJ, Zambrano-Garcia E, Fajardo LV, et al. Antimicrobial profile of Acinetobacter baumannii at a tertiary hospital in Honduras: a cross-sectional analysis. Rev Panam Salud Publica. 2020;44:e46. https://doi.org/10.26633/RPSP.2020.46
\end{abstract}

ABSTRACT

\begin{abstract}
Acinetobacter baumannii is considered to be a worldwide threat to public health due to its high antimicrobial resistance rates and the severe infections it can cause. Little is known about this pathogen's resistance in Central America. This report aims to describe the antimicrobial resistance profile of $A$. baumannii at a tertiary hospital in Honduras. The cross-sectional analysis was conducted at the tertiary care laboratory hospital in San Pedro Sula in 2015 - 2017. A total of 113 consecutive microbiological reports were analyzed, comprising 100 individuals from whom $A$. baumannii was isolated. Epidemiological and microbiological data, including the isolation setting and patient information, were recorded. Prevalence of multi-drug and extensive-drug resistance was assessed according to international standards. The median age of individuals was 22 years (2 - 35 years); female was the predominant gender (53\%). The hospital's pediatric wards had the highest number of isolates $(n=48)$. The most frequent specimen from which $A$. baumannii was isolated was skin and soft tissue $(n=39)$. Resistance to carbapenems was reported to be $40.7 \%$ among the isolates $(n=46)$; multi-drug resistant, $35.4 \%$ $(n=40)$; and extensively-drug resistant, $7.1 \%(n=8)$. This report reveals the threat of this pathogen to public health in Honduras and appeals for antibiotic stewardship programs throughout Central America.
\end{abstract}

Keywords $\quad$ Drug resistance, microbial; Acinetobacter baumannii; drug resistance, multiple; Honduras.

Acinetobacter baumannii is considered to be an opportunistic pathogen that is primarily found in hospitals and causes a diversity of infections with fatal outcomes (1). In 2017, the World Health Organization (WHO) identified carbapenem-resistant $A$. baumannii as a critical pathogen due to its high antimicrobial resistance rates, and set an alert for infections caused by this gram-negative microorganism (2). Mortality and costs due to A. baumannii infections are high, especially where no infection control programs exist (3). According to a recent WHO report, A. baumannii becomes a major threat to public health when it acquires resistance to broad-spectrum antibiotics, such as

\footnotetext{
1 Universidad Católica de Honduras, San Pedro Sula, Honduras. $\triangle$ Julio Cesar Zuniga Moya, jczm1991@gmail.com
}

carbapenems (2). Current findings suggest that the battle against this pathogen is being lost (4) due to the limited alternatives for treating the breadth of infections it causes (5) and a lack of public health interventions to control antimicrobial resistance.

In Latin America, most research efforts examine this pathogen's susceptibility patterns in South America $(6,7)$ and Mexico (8). From a public health perspective, however, Central America is strategically important within the Region of the Americas because it connects and divides North America and South America (9). In Honduras, recent studies $(10,11)$ reveal that $A$. baumannii has novel molecular characteristics of antimicrobial

\footnotetext{
2 Hospital Nacional Dr. Mario Catarino Rivas, San Pedro Sula, Honduras.
} 
resistance mechanisms, results that raise public health concerns regarding implications for the clinical setting. Furthermore, a newer study in Nicaragua (12) describes the presence of $A$. Baumannii carbapenem-resistant strains using molecular tools, underscoring the need to examine the clinical and epidemiological implications of its findings for Central America.

Most research in Central America has focused primarily on the molecular characteristics of isolates. This report aims to describe the epidemiological characteristics, hospital ward, and phenotypical antimicrobial profile of $A$. baumannii at a tertiary care facility in San Pedro Sula, Honduras.

\section{MATERIALS AND METHODS}

A cross-sectional study was conducted at a tertiary health care center in San Pedro Sula, Honduras. The Instituto Hondureño de Seguridad Social is a semi-private tertiary hospital, the second largest in the city of San Pedro Sula and its metropolitan area. This facility provides health care to legally-registered, economically-active individuals and their dependents. It includes a microbiology laboratory and 15 medical specialties for inpatient and ambulatory services, including three pediatric wards.

Convenience sampling identified 113 consecutive microbiological reports comprising 100 individuals from whom $A$. baumannii had been isolated in 2015 - 2017. To meet the inclusion criteria, each microbiological report had to include: an A. baumannii isolate; the patient's age and gender; the type of specimen; the hospital ward; and the resistance profile (with minimum inhibitory concentrations) for each antibiotic.

Antimicrobial susceptibility tests at the Instituto Hondureño de Seguridad Social laboratory were performed using the MicroScan Walkaway $^{\circledR}$ (Beckman Coulter, Inc., Brea, CA, United States), which reports minimum inhibitory concentrations according to the Clinical and Laboratory Standards Institute guidelines (13). Resistance was determined using the described methods, and recorded in an electronic database for further statistical analysis.

For the statistical analysis, the median and interquartile range were calculated for age; proportions were calculated for gender, hospital ward, type of specimen, and resistance profiles. Statistical analysis was performed using $\mathrm{R}$ version 3.6.1. (The $\mathrm{R}$ Foundation, https: / /www.r-project.org/).

The research protocol was reviewed and approved by Institutional Review Boards at Instituto Hondureño de Seguridad Social and Universidad Católica de Honduras.

\section{RESULTS}

A total of 113 microbiological reports from 100 different individuals met the inclusion criteria and were analyzed (Table 1). These individuals had a median age of 22 years (range $=2-35$ ) and more were female (53\%).

Analysis of isolates by hospital ward showed that the pediatric wards (pediatric Intensive Care Unit [ICU], neonatal ICU, and general pediatrics) had the most isolates $(44 \%, n=48)$. Regardless of age group, the majority of isolates $(54.8 \%, n=62)$ came from the ICUs. The specimens from which $A$. baumannii was isolated were predominantly skin or soft tissue $(34.5 \%$, $n=39$ ) (Table 1).

Excluding meropenem, tetracycline, and amikacin, isolates had a sensitivity of $<50 \%$ to the other antibiotics. Only $40.7 \%$
TABLE 1. Demographic and epidemiological characteristics of 100 patients and 113 Acinetobacter baumannii isolates, Honduras, $2015-2017$

\begin{tabular}{|c|c|c|}
\hline \multirow[t]{2}{*}{ Variables } & \multicolumn{2}{|c|}{ Microbiology reports/isolates } \\
\hline & $n=113$ & $\%$ \\
\hline Age (median; interquartile range) & 22 years & $2-35$ years \\
\hline \multicolumn{3}{|l|}{ Gender ${ }^{a}$} \\
\hline Male & 47 & 47 \\
\hline Female & 53 & 53 \\
\hline \multicolumn{3}{|l|}{ Hospital ward ${ }^{b}$} \\
\hline Pediatric Intensive Care Unit (ICU) & 19 & 17.4 \\
\hline General pediatrics & 17 & 15.6 \\
\hline Adult ICU & 14 & 12.8 \\
\hline Ambulatory care clinic & 14 & 12.8 \\
\hline Neonatal ICU & 12 & 11.0 \\
\hline Intermediate care unit & 10 & 9.2 \\
\hline Internal medicine & 10 & 9.2 \\
\hline Surgery & 10 & 9.2 \\
\hline Others & 3 & 2.9 \\
\hline \multicolumn{3}{|l|}{ Specimen } \\
\hline Skin and soft tissue & 39 & 34.5 \\
\hline Urine & 26 & 23.0 \\
\hline Lower respiratory tract & 21 & 18.6 \\
\hline Blood & 20 & 17.7 \\
\hline Others & 7 & 6.2 \\
\hline
\end{tabular}

a Reported from 100 individuals

were missing data for hospital ward.

Source: Prepared by the authors from the study results.

TABLE 2. Antibiotic resistance profiles of Acinetobacter baumannii isolates in Latin America and Honduras

\begin{tabular}{|c|c|c|c|c|c|c|}
\hline \multirow[t]{2}{*}{ Antibiotic } & \multicolumn{2}{|c|}{$\begin{array}{l}\text { Latin America } \\
2009\end{array}$} & \multicolumn{2}{|c|}{$\begin{array}{l}\text { Latin America } \\
2014\end{array}$} & \multicolumn{2}{|c|}{$\begin{array}{c}\text { IHSS }^{\mathrm{a}} \\
2015-2017\end{array}$} \\
\hline & $\bar{n}$ & $\%$ & $n$ & $\%$ & $n$ & $\%$ \\
\hline Ampicillin-sulbactam & 9060 & 53.4 & 10545 & 48.1 & 113 & 53.1 \\
\hline Ceftazidime & 6870 & 61.9 & 9916 & 69.4 & 113 & 63.2 \\
\hline Cefepime & 6863 & 56.9 & 9833 & 63.9 & 113 & 62.8 \\
\hline Meropenem & 6355 & 35.6 & 8947 & 60.4 & 113 & 40.7 \\
\hline Gentamicin & 6853 & 60.8 & 9837 & 60.6 & 113 & 55.8 \\
\hline Amikacin & 6353 & 47.2 & 9559 & 45.6 & 113 & 32.7 \\
\hline Ciprofloxacin & 6871 & 62.8 & 9837 & 68.1 & 113 & 54.9 \\
\hline Levofloxacin & - & - & - & - & 113 & 51.3 \\
\hline $\begin{array}{l}\text { Trimethoprim- } \\
\text { sulfamethoxazole }\end{array}$ & 6290 & 47.0 & 8461 & 63.6 & 113 & 73.5 \\
\hline Tetracycline & 515 & 11.2 & 5636 & 16.6 & 113 & 41.9 \\
\hline
\end{tabular}

a Instituto Hondureño de Seguridad Social (Tegucigalpa, Honduras).

Source: Prepared by the authors from the study results and data from the Pan American Health Organization $(16,17)$, with permission.

of isolates exhibited resistance to meropenem, giving this antibiotic the lowest rate. The hospital ward that reported the highest proportion of meropenem-resistant $A$. baumannii isolates was the adult ICU $(21.7 \%, n=10)$, followed by the pediatric ICU $(19.6 \%, n=9)$. Additionally, the specimens that exhibited the highest meropenem-resistance were skin and soft tissue $(37 \%$, $n=17)$. Conversely, trimethoprim-sulfamethoxazole showed the largest proportion of resistance $(73.5 \%, n=83)$. Cephalosporins averaged nearly $60 \%$ resistance, while aminoglycosides and quinolones averaged about 50\% (Table 2). 
According to the resistance profiles of the A. baumannii isolates studied, $35.4 \%(n=40)$ complied with the definition of multi-drug resistant (MDR) A. baumannii. Additionally, 7.1\% $(n=8)$ were extensively-drug resistant (XDR) isolates.

\section{DISCUSSION}

This study identified patterns of antimicrobial resistance in A. baumannii isolates at a tertiary care center in Honduras and found that nearly $50 \%$ came from its pediatric wards. This result concurs with studies from other countries $(14,15)$ that found the pathogen was predominantly isolated in pediatric wards, especially pediatric ICUs. Notably, at the study hospital, $25 \%(n=2)$ of the XDR isolates were from children compared to the findings of a recent study in Bolivia (15) where the rate was $8.3 \%(n=3)$.

The present study found that $40 \%$ of $A$. baumannii isolates were meropenem resistant. In Latin America, resistance to this antibiotic has increased. In its 2009 surveillance report on antimicrobial resistance (16), the Pan American Health Organization (PAHO) noted that $A$. baumannii was resistant to meropenem at a proportion of $35.6 \%$. However, the most recent $\mathrm{PAHO}$ report (17) shows a substantial rise, to $60.43 \%$, in samples from various countries throughout the Region of the Americas (Table 2). This increase constitutes a major public health concern since carbapenems are considered to be the last resort for treating $A$. baumannii infections resistant to other broad-spectrum antibiotics. When compared to the two PAHO reports $(16,17)$, this study's antibiotic resistance proportions are similar in range, except for amikacin, which was lower $(32.7 \%$ versus $45 \%-47 \%$; Table 2).

In short, these results, which are similar to previous assessments in Latin America, raise public health concerns regarding both the functionality and the deployment of antimicrobial stewardship programs. In response, PAHO has released a special report to strengthen the notification, characterization, and definition of XDR and MDR pathogens (18). However, in a 2015 WHO survey (19), only three countries in Latin America reported having a national plan to combat antimicrobial resistance. In the same survey, 18 Latin American countries responded that in their country, antibiotics could be sold overthe-counter/without a medical prescription.

\section{Limitations}

A limitation of this study was the lack of additional clinical and epidemiological information, such as course of therapy, mortality, and risk factors. Also, it was not possible to determine whether the isolates were colonizations or infections, a determination that would have allowed a better understanding of the pathogen's behavior in the clinical setting.

\section{Conclusions}

A. baumannii infections are a serious public health problem worldwide. This report of a tertiary hospital in Honduras reveals that this pathogen has a high resistance profile, especially to broad-spectrum antibiotics. In light of these results and for interventions to be effective, health care officials in Latin America should commit to international initiatives that seek to reduce antimicrobial resistance patterns.

Author contributions. All authors conceived the original idea of this project. CAC, MLL, MJB, EZG, LVF, and JSP contributed with data collection. JCZ, LER, SAB, and EBS contributed data analysis and interpretation. JCZ, LER, SAB, and EBS wrote the paper. All the authors reviewed the paper and approved the final version.

Acknowledgements. The authors wish to thank the microbiology team at Instituto Hondureño de Seguridad Social for granting access to the susceptibility tests. For assistance with manuscript preparation, we want to give special thanks to Kirsten Herold (University of Michigan School of Public Health, Ann Arbor, MI, United States).

Funding. Asociación Científica de Estudiantes de Medicina, Universidad Católica de Honduras, contributed to the project's logistical needs, including supplies and transportation costs.

\section{Conflict of interests. None declared.}

Disclaimer. Authors hold sole responsibility for the views expressed in the manuscript, which may not necessarily reflect the opinion or policy of the RPSP/PAJPH and/or PAHO.

\section{REFERENCES}

1. Antunes LCS, Visca P, Towner KJ, Acinetobacter baumannii: evolution of a global pathogen, Pathogens and Disease, 2014;71(3):292-301.

2. World Health Organization. WHO publishes list of bacteria for which new antibiotics are urgently needed [Internet]. Geneva: WHO; 2017. Available from: https://www.who.int/news-room/ detail/27-02-2017-who-publishes-list-of-bacteria-for-which-newantibiotics-are-urgently-needed Accessed on March 92020

3. Nelson RE, Schweizer ML, Perencevich EN, Nelson SD, Khader K, Chiang HY, et al. Costs and mortality associated with multidrugresistant healthcare-associated acinetobacter infections. Infect Control Hosp Epidemiol. 2016;37(10):1212-8.

4. Protic D, Pejovic A, Andjelkovic D, Djukanovic N, Savic D, Piperac $\mathrm{P}$, et al. Nosocomial infections caused by acinetobacter baumannii: Are we losing the battle? Surg Infect (Larchmt). 2016;17(2):236-42.

5. Isler B, Yohei D, Bonomo RA, Paterson D. New Treatment Options against Carbapenem-Resistant Acinetobacter baumannii Infections. Antimicrob Agents Chemother. 2019;63(1):1-17.
6. Rodríguez $\mathrm{CH}$, Balderrama Yarhui N, Nastro $\mathrm{M}$, Nuñez Quezada T, Castro Cañarte G, Ventura RM, et al. Molecular epidemiology of carbapenem-resistant Acinetobacter baumannii in South America. J Med Microbiol. 2016;65(10):1088-91.

7. Nuñez Quezada T, Rodríguez $\mathrm{CH}$, Castro Cañarte $\mathrm{G}$, Nastro $\mathrm{M}$, Balderrama Yarhui N, Dabos L, et al. Outbreak of blaOXA-72producing Acinetobacter baumannii in South America. J Chemother [Internet]. 2017;29(5):321-4. Available from: http://dx.doi.org/10.10 80/1120009X.2016.1158936 Accessed on March 92020

8. Bocanegra-Ibarias P, Peña-López C, Camacho-Ortiz A, LlacaDíaz J, Silva-Sánchez J, Barrios H, et al. Genetic characterisation of drug resistance and clonal dynamics of Acinetobacter baumannii in a hospital setting in Mexico. Int J Antimicrob Agents. 2015;45(3):309-13.

9. Davis JR, Lederberg J. Emerging Infectious Diseases from the Global to the Local Perspective. Emerging Infectious Diseases from the Global to the Local Perspective. 2001. 
10. Graña-Miraglia L, Evans BA, López-Jácome LE, Hernández-Durán M, Colín-Castro CA, Volkow-Fernández P, et al. Origin of OXA-23 Variant OXA-239 from a Recently Emerged Lineage of Acinetobacter baumannii International Clone V . mSphere. 2020;5(1):1-9.

11. López-Leal G, Zuniga-Moya JC, Castro-Jaimes S, Graña-Miraglia L, Pérez-Oseguera A, Reyes-García HS, et al. Unexplored Genetic Diversity of Multidrug- and Extremely Drug-Resistant Acinetobacter baumannii Isolates from Tertiary Hospitals in Honduras. Microb Drug Resist [Internet]. 2019;25(5):690-5. Available from: http://doi. org/10.1089/mdr.2018.0311 Accessed on March 92020

12. Dretler AW, Avila J, Sandoval Lira L, García Rener M, Burger-Calderon $\mathrm{R}$, Hargita MN, et al. High Rates of New Delhi Metallo- $\beta$-Lactamase Carbapenemase Genes in Multi-Drug Resistant Gram-Negative Bacteria in Nicaragua. Am J Trop Med Hyg. 2020;102(2):384-7.

13. Clinical and Laboratory Standards Institute. Performance standards for antimicrobial susceptibility testing. Wayne: CLSI; 2019.

14. Chen Y, Ai L, Guo P, Huang H, Wu Z, Liang X, et al. Molecular characterization of multidrug resistant strains of Acinetobacter baumannii isolated from pediatric intensive care unit in a Chinese tertiary hospital 11 Medical and Health Sciences 1108 Medical Microbiology. BMC Infect Dis. 2018;18(1):1-7.

15. Cerezales M, Ocampo-Sosa AA, Álvarez Montes L, Díaz Ríos C, Bustamante Z, Santos J, et al. High Prevalence of Extensively Drug-resistant Acinetobacter baumannii at a Children Hospital in Bolivia. Pediatr Infect Dis J. 2018;37(11):1118-23.

16. Organización Panamericana de la Salud. Informe Anual de la red de monitoreo/vigilancia de la resistencia a los antibióticos 2009.
Available at: https://www.paho.org/hq/dmdocuments/2011/anti bioticos-BookInforme-2009-inside-LR-SepI6.pdf Accessed March 8 2020

17. Organización Panamericana de la Salud. Informe anual de la red de monitoreo/ vigilancia de la resistencia a los antibióticos y de infecciones asociadas a la atención de la salud 2014. Rev Patol Trop. 2014;43(Supl 2):1-108. Available at: https://revistas.ufg.br/iptsp/ article/view/47333/23201 Accessed March 82020

18. Jiménez Pearson MA, Galas M, Corso A, Hormazábal JC, Duarte Valderrama C, Salgado Marcano N, et al. Consenso latinoamericano para definir, categorizar y notificar patógenos multirresistentes, con resistencia extendida o panresistentes. Rev Panam Salud Pública. 2019;43:e65. https://doi.org/10.26633/RPSP.2019.65

19. World Health Organization. Un informe de la OMS revela que los sistemas para combatir la resistencia a los antibióticos presentan deficiencias en todas las regiones del mundo [Internet]; 2015. Available from: https://www.who.int/mediacentre/news/ releases/2015/antibiotic-resistance-lacking/es/ Accessed March 8 2020

Manuscript received on 9 May 2019. Revised version accepted for publication on 3 March 2020.

\section{Perfil de resistencia a los antimicrobianos de Acinetobacter baumannii en un hospital de atención terciaria en Honduras: análisis transversal}

\section{RESUMEN}

Palabras clave
Acinetobacter baumannii se considera como una amenaza mundial para la salud pública debido a sus tasas elevadas de resistencia a los antimicrobianos y a las infecciones graves que puede causar. Es poco lo que se conoce acerca de la resistencia de este agente patógeno en Centroamérica, por lo que el propósito de este informe es describir el perfil de resistencia a los antimicrobianos de A. baumannii mediante un estudio llevado a cabo en un hospital de atención terciaria en Honduras. Entre el 2015 y el 2017, se realizó un análisis transversal en el laboratorio de atención terciaria en el Instituto Hondureño de Seguridad Social en San Pedro Sula. Se analizó un total de 113 informes de análisis microbiológicos consecutivos, en los que las cepas aisladas de A. Baumannii provenían de un grupo de 100 personas. Se registraron los datos epidemiológicos y microbianos, así como el entorno de aislamiento y la información del paciente. La prevalencia de la multirresistencia y la resistencia extensa se evaluó con base en las normas internacionales. La mediana de edad de las personas fue de 22 años (intervalo: de 2 a 35 años de edad) y predominó el sexo femenino (53\%). Las salas de pediatría del hospital presentaron el número más alto de cepas aisladas $(n=48)$. La piel y el tejido blando $(n=39)$ fueron las muestras más frecuente de las cuales se aisló la cepa $A$. Baumannii. Se notificó $40,7 \%$ de resistencia a los fármacos carbapenémicos en las cepas aisladas $(n=46) ; 35,4 \%$ de multirresistencia $(n=40)$; y $7,1 \%$ de resistencia extensa $(n=8)$. Este informe pone en evidencia la amenaza que este agente patógeno representa para la salud pública en Honduras. Asimismo, sirve para alertar a los programas de optimización del uso de antibióticos en Centroamérica.

Farmacorresistencia microbiana; Acinetobacter baumannii; resistencia a múltiples medicamentos; Honduras. 


\section{Perfil antimicrobiano de Acinetobacter baumannii em um hospital terciário em Honduras: uma análise transversal}

RESUMO Acinetobacter baumannii é considerado uma ameaça à saúde pública em todo o mundo devido às suas altas taxas de resistência antimicrobiana e às graves infecções que pode causar. Sabe-se pouco sobre a resistência deste patógeno na América Central. Este artigo visa descrever o perfil de resistência antimicrobiana de A. baumannii em um hospital terciário em Honduras. Realizamos uma análise transversal no hospital terciário de San Pedro Sula, de 2015 a 2017. Analisamos um total de 113 laudos microbiológicos consecutivos, que envolveram 100 pessoas das quais foi isolado A. baumannii. Registramos dados epidemiológicos e microbiológicos, incluindo o ambiente onde foi feito o isolamento e informações sobre os pacientes. Avaliamos a prevalência de resistência a múltiplos fármacos e resistência extensiva, de acordo com padrões internacionais. A idade mediana dos participantes foi de 22 anos (intervalo, 2 a 35 anos); a maioria dos participantes foi do sexo feminino (53\%). As enfermarias pediátricas do hospital tiveram o maior número de isolados $(n=48)$. A pele e os tecidos moles foram os espécimes mais frequentes de isolamento de $A$. baumannii $(n=39)$. A resistência aos carbapenens foi constatada em $40,7 \%$ dos isolados $(n=46)$, a resistência a múltiplos fármacos esteve presente em 35,4\% $(n=40)$ e a resistência extensiva em $7,1 \%(n=8)$. Este artigo revela a ameaça que este patógeno representa à saúde pública em Honduras e faz um apelo pela implantação de programas de gestão do uso de antibióticos em toda a América Central.

Palavras-chave Resistência microbiana a medicamentos; Acinetobacter baumannii; resistência a múltiplos medicamentos; Honduras. 